\title{
Fishers' knowledge and scientific indeterminacy: contested oil impacts in Mexico's sacrifice zone
}

\author{
Liina-Maija Quist $^{1}$ (D) \\ Received: 1 February 2018 / Accepted: 17 October 2018 / Published online: 23 November 2018 \\ (C) The Author(s) 2018
}

\begin{abstract}
In Tabasco, in the Mexican Gulf of Mexico, many small-scale fishers follow their catch to prohibited offshore areas set aside for the oil industry's extractive activities. They claim that increased seismic studies and oil extraction displace and kill fish, contributing to a reduction in hauls, which acts as an incentive to the fishers to continue accessing traditional fishing grounds in the recently prohibited areas. The author draws on theoretical ideas from de la Cadena and Ingold to examine the fishers' offshore movement and related knowledge claims as 'excess', or beyond conventional political discourses, interrogating the multiple and contested meanings that fishers attach to their sea environment, fish and fishing in the context of increased oil extraction operations. The article shows that these meanings are difficult to articulate within a political frame that constitutes the offshore extraction area as a 'sacrifice zone'. However, the respective knowledges of fishers and the oil industry about the industry's impacts on marine life rely on patchy evidence, lack systematicity, and are motivated by political interests. The author argues that scientific indeterminacy about the causes of depleting fish populations and the weakness of environmental legislation exclude fishers' knowledge from politics while recognising the oil industry's knowledge as valid.
\end{abstract}

Keywords Fisher $\cdot$ Knowledge $\cdot$ Mexico $\cdot$ Mobility $\cdot$ Oil industry $\cdot$ Politics $\cdot$ Sacrifice zone $\cdot$ Seismology

\section{Introduction: fishers at sacrifice zone}

It's a scorching early July afternoon ten kilometres off the coast of Southern Tabasco in the Gulf of Mexico. I have joined Carlos, a licensed fish entrepreneur, and three unlicensed sea fishers - Henri, Juan and Manuel, who work for Carlos - on a fishing trip. The horizon ahead of us is dotted with oil platforms. The three fishers know them all by their location. They tie their open fibreglass boat to a small platform next to 'Tsimin'. A major platform, symbolically christened with a Mayan name like all Petróleos Mexicanos's Gulf of Mexico platforms, Tsimin sits majestically atop large subsoil fields of oil and gas that belong to the new oil production project 'Coastal Tabasco'. As sizeable waves beat against the boat, soaking us all, the men swiftly release

Liina-Maija Quist

liina-maija.quist@helsinki.fi

1 Environmental Policy, Faculty of Social Sciences, University of Helsinki, P.O.BOX 54, 00014 Helsinki, Finland their hooked long lines into the water. They know that, like the Gulf's large coral reefs, the oil platforms' reef-like environment also attracts fish and therefore fishers, many of whom are defying recent governmental restrictions on marine traffic in their attempt to make a living. In a bare-handed, silent choreography, the men briskly begin to pull in their long lines, hauling out banderas (gafftopsail catfish) with long venomous spines, which twist and jump in the air in a surprised fight for their lives. Later, the men tell me that knowledge of the movement of banderas, guachinangos (red snapper) and other commercially important sea fish has long been disputed between fishers and the oil industry. I have earlier learned that, in 2003, an area of $15,900 \mathrm{~km}^{2}$ in the Gulf was closed to fishing, ostensibly to protect the oil industry from 'potential acts of terrorism'. While the Mexican government and the oil industry blame fishers for breaching security restrictions and overexploiting the fish, fishers say that increased seismic studies and oil spills displace and kill marine inhabitants, threatening their way of life (Author's fieldnotes, 2011 and 2012). 
The offshore waters of the Gulf of Mexico provide a sociospatially distinct environment for various extractive operations, away from the immediate observation of most people on shore. However, small-scale fishers' travels in pursuit of the fish extend from the coastline to nearly $200 \mathrm{~km}$ offshore. For the fishers, livelihoods and life are based on movement around, within and beyond the Gulf of Mexico's oilproduction areas. But from the perspective of oil industry actors and fisheries and environmental officials, the fishers constitute 'trouble' as they transgress spatial restrictions designed to protect the oil industry and fishing prohibitions designed to protect specific fish species.

Ethnographic studies of maritime livelihoods have commonly focused on fishing instead of other maritime activities (Acheson 1981; Helmreich 2011; Pálsson 1994), with many recent studies examining relations between fishers, the state and conservation agencies in the management of commercial fishing at various scales (Lyons et al. 2016; Pauwelussen 2016). However, the ways in which economically important and politically powerful extractive industries impact on marine ecology and shape the livelihoods of coastal communities have received much less attention. Currently, 33\% of the world's oil is extracted offshore, and both that and deep-sea mining are increasing, accompanied by multiple impacts on marine ecologies and seafaring communities (Maribus 2014).

Political ecologies of oil extraction have recently drawn attention to the role of oil extraction and its infrastructure in shaping the governance of people and the environment (Appel 2012; Barry 2013). However, while these analyses have illustrated how oil's spatial configuration often protects the industry and makes it difficult for popular movements to influence politics (Arroyo and Zalik 2016; Mitchell 2011), we know less about how coastal dwellers manage their everyday activities in terms of offshore operations. This article focuses on two important and understudied aspects of seafaring communities' living with oil: fishers' offshore movement in oil-production areas and their related knowledge about the industry's impacts on fish. I also examine the difficulty of articulating this knowledge with political narratives that are recognised in formal arenas of conflict over access to the sea involving fishing and oil governance.

I follow fishers' movements in coastal and offshore areas to illustrate how their knowledge claims about the impacts of oil extraction on fish are informed by a closeness to the sea environment, constituted through such movement. I further examine how their claims are ignored in politics, allowing offshore waters to be regarded as a 'sacrifice zone' and validating the oil industry's evidence of impacts of their activities. My approach draws primarily on theorisations of humanenvironment relations and radical alterity proposed by anthropologists with an orientation towards science and technology studies (de la Cadena 2015; Ingold 2011), while analysis of fishers is informed by Ingold's understanding of movement and change as essential to sociality and life (Ingold 2011: 148). Indeed, Ingold observes that it is only through movement in the environment that humans (and other living beings) exist as social beings. Hence, to understand how fishers, whose lives are based on movement, 'live with oil', we need to follow how they move in the sea environment where oil is extracted.

Since their patterns of movement produce, shape, and express their relations with their environment, I also focus on an important difference between how fishers themselves describe and manifest their connections with their surroundings, and how their leaders, the oil industry and governmental actors frame them in political discourse. My analysis follows Marisol de la Cadena's theorisation of human-environment relations as 'excess' (de la Cadena 2010; de la Cadena 2015; Stengers 2005), which she conceptualises as "something which is performed past "the limit", meaning that it lies outside generic public framings of a given phenomenon, and is therefore non-existent and non-accessible through conventional understandings - in this case those concerning humanenvironment relations. Based on her fieldwork in Peru, de la Cadena (2015) suggests that the dimension of people's knowing and being in their environment, which transcends the modern nature-culture divide, remains beyond being verbalised as recognisable or acceptable narratives in formal arenas of politics. Likewise, among Tabascan fishers, the embodiedness of their seafaring way of life simply cannot be articulated in words, much less in political claims.

In the study of fishers and oil, conceptualising fishers' lifeworlds as excess within the political sphere assists in analysing how fishers deal with living in the context of extractive politics. In Tabasco, fisher leaders operate as mediators between fishers' claims and politics, reshaping difficult-to-articulate, embodied knowledge into more readily comprehensible political narratives. Attention to this mediation work identifies what remains as excess: that which cannot be incorporated into Tabasco's resource-access politics. Based on my findings, I also suggest that the fishers' way of life may reveal ecological practices that constitute alternatives to current hegemonic modes of governing the world's oceans through intensified marine spatial planning (Boucquey et al. 2016).

The practices of fishing and of oil extraction involve competing valuations of the sea environment. The fishers' seabound movement and their resulting knowledge claims do not adhere to requirements set for legitimate knowledge or for politics. At the same time, the politics of oil construe the Gulf of Mexico production areas as a sacrifice zone necessary for economic progress, and demand of participants in politics a particular rhetoric for claiming access to it. Recent discussions concerning sacrifice zones among environmental justice scholars and others (Klein 2014; Lerner 2010; Morrone and Buckley 2011; Valenzuela Pérez 2016) highlight how political narratives about the necessity of development draw on a more 
or less implicit imperative of sacrificing less valuable forms of life. Within the politics of extraction, this poignantly moral logic implies that the idea of development as shared, greater good inherently demands sacrifice. In the Gulf of Mexico's offshore space, 'development' is enabled through actions of enclosure and securitisation of the oil-production areas. Consequently, access and social monitoring are constrained, and social and environmental harm are externalised in these locations. Furthermore, the weak legal framework regulating the oil industry's environmental impacts and politicalscientific controversy about the impacts of extraction complicate efforts to challenge the expansion of extraction, thereby facilitating the degradation of the marine environment and of small-scale fishers' livelihoods. While on-land oil extraction requires environmental impact assessment, the legislation that regulates environmental impact assessment in offshore extraction is not able to effectively regulate and prevent environmental harm (Vidal Hernández et al. 2012).

As a narrative, the 'development' brought by oil — and the implicit socio-environmental sacrifice this requires-has a long history in Mexico's media and among its politicians and the wider populace (Ferry 2005: 211; Quist and Rinne 2017). Since the nationalisation of oil by President Lázaro Cárdenas in 1938, the narrative has valued oil as a patrimonial resource and a symbol of national pride. The popularity of the narrative of oil as patrimony among Mexicans has also complicated efforts by social movements to raise discussion about wide-scale environmental contamination caused by the oil industry (Quist and Nygren 2015; Zalik 2006). However, with declining oil production and decaying infrastructure, Mexico's President Enrique Peña Nieto introduced in 2014 an energy reform to privatise the oil industry. With the privatisation of the patrimonial asset, public protests against Petróleos Mexicanos (PEMEX), currently the world's tenth biggest oil company, have surged, and may undermine the patrimony narrative (Olivares and Gómez 2017).

At the same time as popular criticism of PEMEX has increased in Mexico, questions about the social and environmental sustainability of marine resource extraction in Tabasco's coastal areas have been raised. After a 13-year conflict between fishers and the oil industry over access to sea space, during which catches have substantially decreased, President Peña Nieto announced in 2016 a federal plan to reopen to thousands of fishers an area of $10,000 \mathrm{~km}^{2}$, part of the $15,900-\mathrm{km}^{2}$ securitised zone of exclusion (Comisión Nacional de Pesca 2016), to boost a local coastal economy that has suffered the effects of the oil industry's recent decline. Peña Nieto also declared that a study of the Gulf's marine life and fishing practices would be carried out (Comisión Nacional de Pesca 2016) to reconsider access policies in the oil-production area. However, concerns have been raised that state authorities do not possess systematic knowledge of marine fish stocks as they have not been studied for 10 years
(Editorial Staff and Delgado 2016; Martínez 2017), and new studies by the National Fisheries Institute (Instituto Nacional de Pesca) will not be finalised before June 2018 (correspondence with SAGARPA, 2017). Furthermore, the plans for reopening the exclusion zone for fishing have been made public concurrently with the oil industry's expansion into new areas in the Gulf of Mexico (Televisa 2017). The intensification of oil extraction has been carried out without examining the social and ecological viability of the two industries' coexistence.

The focus of this paper is the disjuncture between the fishers' movement-bound knowledge and the logic of sacrifice, in a context where law and politics allow profound scientific indeterminacy about the impact of seismology and pollution associated with oil production to matter in specific ways. Globally, recognition of the environmental and health risks of oil has long been heavily influenced by uncertainty and controversy (Auyero and Swistun 2009; Lerner 2010; Sawyer 2016). In the case of highly complex marine ecosystems, it is difficult to distinguish between oil industry-related and other factors of environmental degradation. This is particularly the case for seismological studies, which are limited and inconclusive. For example, recent studies about the relation between seismic exploration and fish behaviour suggest that the noise of airguns used in seismology disrupts fish behaviour and may harm the hearing and reproductive cycles of several marine species (Payne et al. 2012; Paxton et al. 2017). Furthermore, there is no scientific literature on the long-term impacts of seismic exploration on ecosystems (Paxton et al. 2017). In Tabasco, the scientific indeterminacy of possible impacts of seismological exploration inevitably creates room for struggles over legitimate knowledge about it.

The following section provides the context of Tabasco's fisher communities and oil extraction, and documents the methodology employed in this study. Thereafter, I show how fishers constitute their daily aquatic lives through their relations with the environment while the legislative politics and oil industry actors' narratives of oil constitute Tabasco as a sacrifice zone. I go on to discuss how fishers' claims for sea space are connected to their sea-bound lives, arguing that the fishers' embodied experiences and knowledge claims remain beyond both articulation and access as acceptable political narratives. In other words, they are 'excess' in terms of the politics of marine resource access, which excludes embodied understandings about human-environment relations inconsistent with hegemonic narratives about patrimony.

\section{Studying fishers' and the oil industry's knowledge in Tabasco}

The study is based on 4,5 months of ethnographic fieldwork within Tabascan fisher communities and 2 months among oil- 
industrial and governmental actors on the coast and in Tabasco's capital, Villahermosa, in 2011-12 and 2017. During this time, I lived with the family of a political leader among the sea fishers, and later with an unlicensed fisher. The fieldwork involved participation in, and observation of, fishing activities among three fisher families and several groups of unlicensed fishers in the river delta, along the coastline and $10 \mathrm{~km}$ offshore, in the course of 13 fishing trips which lasted from 4 to $10 \mathrm{~h}$. During these trips, I either participated by helping to row or was merely a passenger, meanwhile observing the use of gill nets, throw nets and long lines, and the fishing of gafftopsail catfish, red snapper, snook and tilapia, among others. In addition, I observed onshore fishing-related activities from the making of fishing nets to the cleaning and selling of the catch.

Fieldwork included participation in meetings with fisher leaders, fishers, the oil industry and the government. Topics addressed in these meetings included the monitoring of and negotiation over the implementation of compensation that oil companies paid to fishers. Participation in the fishers' lives provided insights into their daily fishing activities, social networks and political strategies. This part of the study included 20 ethnographic interviews and 40 informal conversations with fishers, as well as 25 interviews with oil industry and government representatives. A review of governmental policies and documents of a court case involving contamination caused by PEMEX in fisher and farmer communities also informed this study. Access to the complex networks of Mexican fish-and-oil politics required time and considerable flexibility in empirical data collection. The sensitivity of the research topic, and the politically tense relations between the oil industry, government authorities and different fisher groups, required considerable negotiation to build trust and protect the informants' anonymity.

Tabasco's coastal areas are home to lagoons and a river delta which, together with the vast offshore area, provide the environment for a wide range of marine products from coral reef and marine fish to oysters and crabs. Tabasco's fishers are small-scale fishers who are either self-employed or work for small fishing entrepreneurs. Between the river delta and the $200-\mathrm{km}$ offshore limit, groups of three to five sea fishers, using nets and long lines, work from open fibreglass motor boats and wooden kayaks to catch gafftopsail catfish (bandera), king mackerel, snapper (guachinango, pargo), snook (robalo) and wahoo (peto) (Mendoza Carranza et al. 2008; Saury Arias 2010: 78-82). Federal statistics on fish catches indicate a $22 \%$ decrease in catches of the most important species between 2004 and 2013; these are at best suggestive, however, as they rely on catch reports made by licenced fishers and exclude catches by unlicensed fishers (INEGI 2014; Saury Arias 2010). Although the number of unlicensed coastal and offshore small-scale fishers has increased as campesinos (peasant farmers) have turned to fishing for subsistence, the total number of small-scale fishers has fallen from at least 10,000 in 2004 to between 7000 and 8000 in 2014 (Interview with fishing official, 2011; INEGI 2014; Muñoz-Sánchez and Cruz-Burguete 2013; Saury Arias 2010: 4). These figures are rough estimates based on interviews with government fishing officials in 2011, studies and federal statistics. The decrease in fish catches has taken place since the federal Secretariat of Agriculture, Livestock, Rural Development, Fisheries and Food (SAGARPA) stopped issuing fishing licences to new fishers in the early 1990 s, an initiative justified by an official discourse of conserving fish populations. Despite the decrease of fisher numbers, however, most families in coastal areas still depend on fishing for income.

The communities engaged in fishing are highly heterogeneous in terms of their socio-economic circumstances and ethnicity, and in their status in the fishers' political-organisational hierarchies. Of the 7000 to 8000 small-scale fishers who are active in the coastal river delta, lagoons and offshore, half are unlicensed (pescadores libres $)^{1}$ while the rest are cooperative fishers or licence-holding entrepreneurs (permisionários), who do not usually fish themselves. In addition, many people move between fishing and farming depending on the time of year. While most fishers from the coastal communities are mestizos, some riverine fishers speak Yokot' ${ }^{2}{ }^{2}$ as their mother tongue (Muñoz-Sánchez and Cruz-Burguete 2013). Fishers and fishing entrepreneurs include local fishers, many of whom come from long lines of fisher families, and mestizo migrants who moved to Tabasco from Veracruz in the 1980s. Many of the unlicensed fishers are ex-cooperative members, half of whom now work under casual arrangements for the wealthier permisionários while the rest are informal, independent fishers. The proletarianisation of the fishing communities, the competition for restricted space and the large number of unlicensed fishers who have limited political rights inevitably fragment their political agendas.

Since the Mexican revolution, the state has played a key role in the development of commercial fishing at every level, and state management of it continues to be highly centralised (Greenberg 2006). The federal government actively promoted cooperative fishing from the 1940s to the early 1980s, during which time it focused attention on specific species and encouraged cooperatives to take big loans, which led to the overexploitation of tuna, for example, and the overcapitalisation of the fleet (Greenberg 2006). During the 1980s in Tabasco,

\footnotetext{
$\overline{1}$ Based on estimates by a government fishing official (Interview, 2011).

2 The Yokot'an indigenous group, also called Chontal, Maya-chontal or Maya-putún, is Tabasco's only indigenous group. The majority of Yokot'ans live in the municipalities of interior Tabasco. Many of those living in the coastal municipality of Centla are riverine and lagoon fishers.
} 
coastal people formed cooperatives to begin working in the booming offshore shrimp and fish industries (Interview with environmental NGO 2011). In the 1990s, the Mexican government opened the fishing industry to private investment. Due to increasing debts, cuts in government subsidies, overfishing and PEMEX's operational expansion, fishing suffered, especially the shrimp industry, which eventually collapsed in the 1990s. What remains in Tabasco after the downfall of large-scale commercial fisheries are the small-scale fishers. SAGARPA does not effectively monitor fish populations or the catch of undersized and seasonally banned fish, although both are officially its responsibility. Finally, while Tabasco only accounts for $2.5 \%$ of national fish production (Conapesca 2013), it is Mexico's biggest producer of red snapper and the second biggest producer of prawns, oysters and snook.

Turning to the oil industry, PEMEX, the tenth-largest oil company in the world and the fourth-largest exporter of crude oil to the USA (US EIA 2016), has had an active presence in the everyday life of the coastal communities since it initiated the development of Tabascan offshore oil reserves in the period from 1977 to 1980 (Quist and Nygren 2015: 46). Today, the giant Sonda de Campeche (Campeche Sound) complex in the Gulf of Mexico accounts for 53\% of Mexico's oil production (García 2017), with over 200 oil-production platforms and roughly 160 foreign companies operating there as suppliers. In Tabasco, the number of foreign subcontractors and offshore seismic studies has increased since the early 2000 s and, in 2003, the government imposed security restrictions near oil installations in the Gulf of Mexico in a $15,907 \mathrm{~km}^{2}$ marine zone of exclusion, established under federal law Acuerdo Secretarial No. 117 (DO 2003). This was justified on the grounds of the risk of terrorism and to enhance security. Yet research suggests that one of its aims seems to have been to avoid offshore confrontation, thus ensuring undisturbed oil production (Quist and Nygren 2015).

The wide-scale and long-term environmental impacts of the oil industry have been well known to the Gulf of Mexico's coastal communities since the enormous blowout of the offshore well Ixtoc in 1979, the world's third-largest oil spill, which dumped more than 3.4 million barrels of crude into the Gulf (Soto et al. 2014). However, in addition to numerous more recent accidents such as the blowout of the Ucumacinta oil well in 2007 and accidents occurring during seismic studies, it is the accumulation of smaller-scale, everyday contamination that characterises local experiences of living with oil's environmental risks. The sheer infrastructural presence of the industry also complicates the mobility and livelihoods of fishers, who are obliged to avoid getting in the way of the oil industry's boats, and to be wary of tearing fishing nets on the network of ducts placed uncovered on the seabed in the Gulf's shallow waters (Arias Rodríguez and Ireta Guzmán 2009; El Expreso de Campeche 2016).

\section{Hunters and prey}

Among Tabascan fishers, mobility requires toughness, a tacit understanding of the environment, technical skills and smooth cooperation among boat crews. Daily narratives about fishing portray fisherfolk through tropes evoking mobility and freedom regarding fish, the marine environment and fishing gear. To highlight their 'fisherness', men spoke to me with affection and knowledge about certain difficult-to-reach offshore ridges and branches of rivers where they customarily fished or stayed overnight during long trips. Their narrative accounts portrayed Tabascan men's territories, claimed through decades of moving around offshore, and their knowledge of these waters construed places to which generation after generation of fishers returned. Knowledge about and affection for the sea were thus intimately bound up with fishers' daily moving across it (Ingold 2011).

It was clear that the fishers felt that these places in and around the water belonged to them and were integral to their identity. Their sense of ownership also involved a nationalist sentiment reflecting the number of foreign oil workers who were now occupying many of these areas. Thus, while fishers often said that they did not mind sharing the sea space with fishers from neighbouring states because they knew the others came 'por necesidad' (due to necessity), they spoke resentfully about the white foreigners who worked for offshore oil companies with salaries much higher than those of Mexican workers, referring to them as gringos.

One of the yearly highlights of coastal fishing was the night fishing for robalo machin (snook) in the river delta. This event drew fisherfolk from all the riverine villages in November and December to meet the schools of snook en route from spawning in the freshwater lagoons back to the sea. On these nights, queues of up to 50 boats formed, waiting for their turn to throw their net, allowing the current to transport it a few hundred metres towards the sea before dragging it in. I undertook one of these quiet, nightly fishing trips with two unlicensed fishers 2 months after a fatal offshore accident that had taken place during a storm on a foreign company's vessel carrying out seismic studies off the coast. While we queued to throw our net, the two fishers wondered whether the company was going to restart work after the accident or wind down its operations: 'The gringos must be afraid of us, as they are going home,' the young men joked assertively (Author's fieldnotes, 2011). The joking heightened the sense of being part of the water space, of belonging to it and owning it. It communicated a masculine, protective relationship with the river that did not welcome actors who competed for space with fishers.

Those who could still afford to travel offshore beyond the restricted zones usually spent 3 to 5 days on their fishing trips. Many men who fished close to the Campeche Sound area with its coral reefs sought a ridge called Cayo Arcas, located in 
shallow waters over a hundred kilometres from Tabasco's coastline, to rest and gain shelter from storms. According to fishers, this ridge, which, due to surrounding reef hazards, was very difficult to reach, and the unbound sea belonged to $l a$ zona de los pescadores (the fishers' zone). Before the introduction of restrictions on movement in the Gulf of Mexico, fishers had been allowed to fish freely around marine oil platforms and to take shelter near the rigs and near Cayo Arcas. But due to the ridge's strategic proximity to the huge Campeche Sound oil installations, it has occasionally been closed off to fishers, leading to disputes. Illegal access to zones of exclusion incurs a fine of 200 pesos per violation, and if a fisher is caught three times, his boat is confiscated. However, as the Gulf lacked effective surveillance, many fishers defied the restrictions.

Much as dwelling (Ingold 2000) in the marine environment is what makes the fishers, the technology of fishing also plays an important role (Pálsson 1994). Fishing requires the swift collaboration of two to five people operating long lines, nets, motors, boats and a radio, drawing on their tacit, bodily knowledge of their equipment and the sea. The good management of fishing gear and boats is a source of pride, and those who took me out on their boats often spoke disparagingly about those whom they did not consider 'proper' fishers because they lacked skill, ambition or a sense of responsibility towards maintaining nets, motors and storage space for caught fish. In a conversation about lending equipment to young, inexperienced fishers, two unlicensed sea fishers discussed the issue of responsibility:

Rodrigo: How could he think I would lend my motor to somebody who is just a kid?I have never lent my motor to anyone! I only trust myself! The responsibility for it is MINE.

Arturo: If I am the patrón de lancha (skipper), I do not give the boat to just anybody.

Rodrigo: Me neither. The day you do it and something happens, you are responsible. Why would I give my boat to a kid, who is just a KID, who does not have any skill? If he falls in the water, he will drown. (Group interview with unlicensed sea fishers, 2012)

The conversation resonates with popular Mexican narratives about equipment as inalienable patrimony, passed from one generation to the next and securing the continuity of patrimonial communities by uniting fathers and sons (see Quist and Rinne 2017). However, the discussion about responsibility highlights especially the necessity to survive by remaining mobile; securing equipment, and hence mobility and livelihood, is primarily a question of securing life.

The pride in being a fisher, however, was perhaps most forcefully expressed in the way fishers traversed the sea by 'turning into' marine creatures themselves. The silent language of their movements as they directed the boat towards the horizon of oil platforms, operated the throw nets near the river delta's mangroves, and put on their masks and flippers to catch lagoon fish, expressed courage and affinity for their way of life. During their fishing operations, they spoke about fish as if of their peers. Hence, during a nightly fishing trip along the coast to catch cinta (cutlass fish) with nets and long lines, fishers laughed in amazement at the dozens of fish that surfaced as if dancing, passing fond comments on their unusual numbers and funny tricks, suggesting they felt the coming of a storm (Author's fieldnotes, 2012).

Sometimes fishers also communicated information about themselves by joking about their catch. Álvaro, an elder fisher, for example, claimed that the meat of the long, alligator-like pejelagarto (tropical gar) worked like Viagra. Curiously, the pejelagarto is unique to the Tabasco River delta ecosystem, and, according to studies, has remained relatively unchanged since it appeared over a hundred million years ago in the Cretaceous period (Spitzer 2015). Álvaro's claimed knowledge about the pejelagarto, although expressed jokingly, implies a special connection between fishers and the predatorprey which inhabits only their waters (and is a delicacy in Tabasco). It seemed as if he was positing a parallel between hunter and prey, both masculine and place-bound.

Through these everyday practices and stories about fish species, fishing items and important places, small-scale fishers construed them as part of their biographies of becoming and being fishers. Yet because of their intensively embodied and affective character, these human-environment entanglements cannot be fully verbalised. Thus, they exceed the frames of acceptable political discourse, occupying less visible margins within the constituting of the Gulf of Mexico as a sacrifice zone. The fishers' profound affinity with their lifeworld would be expressed in passing remarks, such as when Álvaro commented to me that, unlike oil, which would one day come to an end, fish would always continue to exist. His comment highlighted both his pride in mastering a livelihood and way of life nearly as old as humankind, and a faith among fishers in its future.

\section{Politics of sacrifice}

After the privatisation of PEMEX in 2014, in the aftermath of President Enrique Peña Nieto's election, the state narrative of 'development' in the name of oil as patrimony has become harder to defend to Mexicans. In Tabasco, however, although more than three decades of oil extraction has decreased marine biodiversity, reduced fish catches and slowly destroyed coconut cultivations and small-scale agricultural land along the coast (see also Arroyo and Zalik 2016: 136-137), there are few legislative avenues for environmental activism.

Within Mexico's environmental legislation, rewritten when the oil industry was privatised, oil is prioritised over marine 
ecology. The new National Agency for Industrial Safety and Environmental Protection for the Oil and Gas Industry, ASEA, created after the privatisation, lacks comprehensive legislation regarding marine-environmental contamination (Gobierno de México 2016; Sellers 2016). Furthermore, according to an environmental NGO, public hearings, regulated by the law, on projects to be carried out in the coastal zones are often not organised, regardless of coastal communities' demands for them (Consejo Ciudadano por el agua del estado de Tabasco 2014: 10-11). These and a concurrent withdrawing of resources for local monitoring make it impossible to prevent environmental disasters.

Because the environmental legislation regulating the responsibility for the oil industry's marine-environmental impacts lacks effective mechanisms that enable the monitoring of the impacts, it is extremely difficult for fisher communities to obtain legal recognition of, and compensation for, harmful impacts on their livelihoods. A class action law introduced in 2012, which was considered a modest victory by Mexico's environmental NGOs, apparently made it possible for groups of at least 30 people to raise class action claims for environmental damage caused by the oil industry. Soon after its introduction, a group of fishers and small-scale farmers from the interior of Tabasco used it as a basis for suing PEMEX, its subsidiaries and the government institutes involved for damage caused to the environment, residential buildings and local livelihoods (Asociación Ecológica Santo Tomás 2013; Inter Press Service 2013). In 2017, however, the Tabascan judge presiding over the case concluded that as the law only provided that 'authorities with judicial power to commit unilateral acts' could be sued, and as PEMEX was not considered such an authority, PEMEX could not be held legally responsible for environmental damage. Instead, the judge cited the environmental authority PROFEPA (i.e. the federal prosecutor for environmental protection) for failure to inspect and oversee PEMEX's activities, recognised the fishers and farmers affected as entitled to legal protection against environmental harm, and ordered PROFEPA to repair the damage (State of Tabasco 2017). Whether the judgement will actually lead to the restoration of affected soils, buildings and livelihoods, and whether it represents a shift in the politics of the oil industry's environmental impacts, remains to be seen.

In this legislative context, and given the inability of science to establish clear causal relationships to explain the decrease in fish populations, extra-legal politics has gained heightened relevance. Although various state instruments from the federal environmental protection agency (SEMARNAT), PROFEPA and Tabasco state secretariats are involved in the evaluation of harm and negotiations over compensation, the legislation requires no involvement of a non-state entity, leaving the fishers unsupported. Fishers' evidence of oil spills is studied by PROFEPA and private laboratories hired by the oil industry, while impacts of seismic studies, which are often more difficult to prove, are reported by the oil industry to be studied by the industry itself.

When asked in interviews about the impacts of oil spills on the marine ecosystem and fishers, representatives of oil companies usually denied the veracity of spill claims, referring to studies produced by the oil industry, discussing natural effects of oil in the offshore, and suggesting that fishers systematically fabricated evidence.

We carry out various studies and preventive activities. There are no harmful impacts. On the contrary, people are grateful that we are here. We have given them boat motors and fishing equipment but they always want more (laughs). (Interview with PEMEX representative, 2012)

In the case of damaged fishing nets, they may have been impregnated with crude. Another possibility is that there have been emanations of oil that have occurred naturally. So, when there are natural emanations, the crude usually moves away from the coast. But when there's a storm, the crude is swept close to the coast, damaging fishing nets. (Interview with PEMEX representative, 2011)

One needs to have caution, because the fishers stain them [fishing nets] with crude. (Interview with PEMEX representative, 2012)

As with their denials of damage to the nets, oil industry representatives made dubious claims about the impacts of seismic studies, suggesting that the evidence was flimsy. Generally, three-dimensional offshore seismic studies are carried out by 'gunboats'. The studies involve a time-consuming laying of registering cables equipped with hydrophones on the seabed with the help of 'cable boats'. After the cables are placed, fast-moving gunboats drive over the cables, shooting compressed air at them. The hydrophones register the potential existence of subsoil deposits of oil. I asked David, a boat mechanic working with a subcontractor company's gunboats, if people working on the gunboats ever saw dead fish coming up to the surface as a result of seismic shooting. He said the shooting always begins with what in the oil industry is called a 'soft start', meaning that the volume of shots grows sequentially. According to him, it allows fish to move away without being killed (Author's fieldnotes, 2011). Presenting a slightly contradictory narrative, a representative of the same company later claimed that fish do not even swim off:

About the issue of scaring fish away: we even had a fisher go with us on a boat ahead of the gunboat, and what we saw was that the fish were not swimming off. 
(Interview with a representative of a subcontractor company in charge of offshore seismic studies, 2012)

A representative of PEMEX placed the discussion on seismic studies in the wider context of decreased marine species:

The species living on the seabed such as shrimp and oyster would be the first to be affected by seismic studies. But the effect is not only caused by the seismics. It is often the shrimping boats. And the decrease is also because the resource has been over-exploited; many studies prove it. It is not only because of the oil industry. (Interview with PEMEX representative, 2012)

In the same interview, the representative sought to avoid discussing the impacts of seismology by referring to shrimping as environmentally harmful, which has indeed been recognised by scientists. Nevertheless, his statement, and his use of the words 'also' and 'not only', puts the blame partially on shrimpers but does not deny the complicity of the oil industry in reducing the Gulf's biodiversity. This statement does not address the actual complexity of interrelations between different causal factors and fish populations.

Along similar lines, governmental actors interviewed in the course of fieldwork generally discussed the sustainability of commercial fishing as if separate from its relations with the oil industry. According to one official, the primary mission of the federal agency SAGARPA, which regulates fishing licences across the whole of Mexico, was securing limits to fishing, as it 'cannot keep growing like a snowball' (Interview in 2012). Hence, the most recent legislative tools (DOF 2012, DOF 2014a, 2014b) published by the federal government for the regulation of fishing require a decrease in the size of shrimptrawlers and a ban on increasing the catches of red snapper, shrimp and crabs (langosta, jaiba) until an ongoing study of their populations has been carried out, the last studies having been conducted from 2005 to 2007. However, as a Tabasco state official confirmed, in terms of effect, regulation is highly centralised and lacks funds for inspection and monitoring.

Finally, these politics of intensified hydrocarbons and seafood extraction rely on sacrificing the Gulf area and its diverse inhabitants to the national economic interest (Arroyo and Zalik 2016). According to Álvaro, 'the oil companies have not given anything but misery to the people in the Gulf of Mexico' (Interview, 2017). In the current context of economic recession due to the drop in oil prices, the federal state has taken up the narrative of reactivating Tabasco's coastal economies through more effective exploitation of the Gulf's fisheries in 2017. However, the potential reopening of fishing areas as a concession seems to sidestep the issue of assessment of the long-term environmental impacts of the oil industry.

\section{Claims about the disappearance of fish}

Among fishers, knowledge claims about the relationship between fishing and oil emerged from the everyday life experience of the aquatic spaces where fishers moved, as described above. The fishers were all certain that the oil industry was the cause of decreasing fish catches, but their explanations of how the industry impacted on fish varied. Their knowledge was based on first-hand evidence and deduction, and it often included gaps. The diverse groups of fishers who plied the river delta, coastal lagoons and offshore spaces often discussed the migration of fish species away from their former habitats. Álvaro, the leader of the sea fishers, resented the fact that while many other states with a coastline had a CRIP (Centro Regional de Investigación Pesquera, Regional Centre for Fishery Studies) for the purpose of studying aquatic life, the federal authorities had not granted Tabasco its own, which would have been useful for investigating the disappearance of fish. Sea fishers I interviewed remembered the days when fishing trips used to yield 20 tons of different varieties of snapper.

José: Now in order to catch snapper we need to travel 45 to 50 nautical miles, or more.

Manuel: 70 miles.

Juan: The fish are moving further out, further out. They are being depleted! Something's going on.

José: We have to move to new places because here our past way of life is finished. (Group interview with unlicensed sea fishers, 2012)

Different fishers suggested that the emigración and desaparición (migration and disappearance) of species was related to oil spills, sometimes to climate change and overfishing, but especially to the increasing seismological studies carried out along the coast, which were both killing fish and driving them away.

Diego: There was a lot of trout, fat snook, common snook, horse mackerel, cutlass fish here, but they [PEMEX] bombed along the coast and the fish died.

Liina-Maija: How do you know that the fish die because of PEMEX?

Diego: Because the bomb breaks its ... [covers his ears].

But PEMEX says the bombing has no effect on fish.

(Interview with the leader of a cooperative, 2011)

Similarly, an unlicensed sea fisher, Antón, said he had seen how the detonations 'make fish grab air inside themselves and die' (Author's fieldnotes, 2012). Another unlicensed fisher, Matías, who was active in the river delta and along the coastline, said, 'During the time that I've been fishing here, we do 
not know where the fish go, but I tell you it is because this company [referring to a private subcontractor] is working there. They went dynamiting there, which scares the fish offshore, and here at the coast there are none' (Author's fieldnotes, 2011). A retired third-generation fisher and former leader of fishers, Rogelio, remembered the abundance of shrimp, snook, gar and especially shark in the river delta and the coast: 'There used to be plenty of shark from January to July. They disappeared because of the noise. The shark is very sensitive to noise' (Interview, 2012). In my discussions with Álvaro, he said that fish driven away by seismological studies take 5 years to return to their habitats.

However, the narratives were not only about what fishers thought were the causes of fish displacement; they also reflected how they felt about their own unjust marginalisation by the politics of sacrifice. As an elderly unlicensed fisher, Rubén, who fished along the coast, said, 'Well, the port officials and the companies order us to give them space, but we cannot because that area is where the fish take refuge' (Interview, 2011).

Many of the sea fishers who fished far offshore had seen oil spills, but Álvaro said fishers were usually able to avoid catching contaminated fish; its smell was an easy indicator of whether it had been in contact with oil. However, many claimed that the oil industry also damaged their fishing equipment. Fishing nets got torn by passing oil industry boats and by PEMEX's petroleum cables located in the Gulf's shallow waters. Nets were also seen to be spoiled by leaks from oil platforms and tubes: 'Earlier, fishing equipment lasted three, four years; today only six months' (Author's fieldnotes, 2011).

As for the controversial question of overfishing, the fisher leaders' response was generally to argue that fishing activity had not increased as such. 'The truth is that there are more of us today, but fishing efforts remain the same. There is talk about overexploitation because PEMEX is taking away our space' (Interview with Ricardo, a fisher leader, 2011). The claim that the number of fishers had grown, however, was in stark contrast with federal statistics, which indicated the opposite. By drawing attention away from harmful fishing practices in this way, Ricardo highlighted that the harm to fishers was not caused by fishers themselves but by the oil industry's activities and a government that prohibited the catch of black snook and fat snook, for example, which, as fisher leaders argued, were actually abundant because they were not overfished.

Let me explain you about overexploitation. In 1982-83, there were 105 offshore shrimping ships and 2,500 offshore fishing ships in our town. We fished red snapper, gafftopsail catfish, shrimp, escolar and common snook. Today we don't get those quantities. The species have migrated because of contamination. When there's an oil spill, they pour in a powder that makes the petroleum sink to the seabed. It takes four, five years until the flora and fauna are renewed. The oil well Ucumacinta exploded four or five years ago and two million barrels of oil spilled out ... that killed the fish production. The species migrate. PROFEPA did a study of it but there was never a result. That's why we want a study when there's an oil spill. (Interview with Álvaro, 2011)

The credibility of Álvaro's placing the blame on the oil industry is coloured by his first-hand experience of the effects of oil-well blowouts. Nonetheless, it is true that there are few studies on the long-term effects of oil spills in the Gulf of Mexico (Arroyo and Zalik 2016), although some findings of dangerous polycyclic aromatic hydrocarbons and heavy metals in Campeche Sound's shrimp species exist (Rendón von Osten and Villalobos Zapata 2010: 557). Arguments have also been made by some scientists that oil spills may have contributed to the collapse of populations of large pink shrimp in the Gulf of Mexico in the 1980s (Soto et al. 2014).

Unlike the fisher leader Ricardo, many practising fishers expressed concerns about the increased number of people fishing. Rogelio said the fishers needed a consciencia ecológica (environmental awareness) because the government did not monitor seasonal bans and prohibitions on undersized fish. Consequently, fishers would need to self-regulate catches. In practice, however, while some Tabascan fisher groups do self-regulate in small coastal lagoons (Mendoza Carranza et al. 2008), in the open sea, where thousands of fishers operate, regulation has been virtually impossible due to lack of support from the government. In the current situation of decreasing catches, overfishing may indeed be on the rise. This, however, does not rule out the possibility that the oil industry is the main cause of diminished catches.

The everyday narratives about oil, seismology and overfishing quoted above were recounted by diverse individual fishers and their leaders. They constitute a common claim about the overall effects of oil and seismology, despite fishers often being unaware or divided about how exactly technologies and marine ecosystems interact. In line with Ingold's (2011) theoretical ideas about movement, the fishers' claims were rooted in a way of life based on following fish to their shifting habitats and a sense of affinity with the catch. My fieldwork with the fishers suggests that their ways of articulating their tacit knowledge of the ecosystem were linguistically inadequate for political claim-making, especially as much of the knowledge appeared as a mix of inarticulate, embodied everyday practice and affects. However, it was exactly the everyday entanglement with their sea environment that constituted the fishers' identity. As I will show below, the fishers' knowledges were excluded from mainstream discourses by law and politics, which favoured the oil industry. Corresponding with de la Cadena's theorisation (2015), the fishers' knowledges and relations with the environment 
extended beyond politics because they did not conform to the divide between nature and culture accepted by formal politics.

In order to formulate claims over rights to their sea environment, therefore, fisher leaders were forced to relate to popular and state narratives about oil as patrimony. (For further analysis of these claims, see Quist and Rinne 2017.) These narratives, together with state politics of oil, subsume ideas about the inevitability of environmental degradation. Thus, when the newspapers report on environmental contamination and social harms caused by the oil industry as unjust but unavoidable sacrifice due to the impunity of the oil industry, they reshape the fishers' claims as claims over patrimony (Quist and Rinne 2017). Correspondingly, government and oil industry officials highlighted the economic necessity of the paraestatal PEMEX regardless of wide-scale contamination and harm to local livelihoods.

The pressure to acknowledge PEMEX's importance as an 'engine of development' and symbol of patrimonial assets was reflected in Álvaro's and other fisher leaders' narratives. The leaders made it clear that they were pressured to 'know' that from the point of view of Mexicans, PEMEX was the primary concern, but also claimed that its coexistence with fishers had to be made possible (Quist and Rinne 2017). In their everyday lives fishers seldom referred to patrimony, but rather posited access to the environment as a right to a particular way of life and to dignity. This understanding, however, did not inform the collective political claims formulated by fisher leaders. Rather, the legislative-political setup incentivised fishers to present their case in terms of economic value, which could not represent the rich meanings they associated with the sea space. Hence, while fishers themselves, through their daily discourse and practice, expressed mobility in, and intimacy with, the sea environment as a way of life, fishers' political leaders like Álvaro operated as mediators who translated this excess into political narratives about patrimony and economic value, which were acceptable in the arenas of Tabasco's environmental governance, in which rendering the oil production zone as a sacrifice was portrayed as imperative.

\section{Conclusion}

In this article, I have argued for recognising that fishers' practices and narratives of following fish - underpinned by their understandings of marine ecology, seismology and oilcannot be articulated into political narratives, despite having political relevance. Commonly, political ecologies of oil and ethnographic studies of maritime livelihoods do not examine the complex relations between fishing and the oil industry. I have shown that the fishers' movements through offshore and coastal environments, and their narratives of their understandings of the disappearance of marine species, reflect how the 'world' of diverse fisherfolk both communicates with, and exceeds, narratives recognisable within the politics of offshore access. At the same time, these politics, in which legislation is operationalised for the intensified extraction of offshore oil, shape the Gulf of Mexico and its diverse inhabitants as a sacrifice zone. The sacrifice of less valuable forms of life to serve the common good reflects historical state narratives of oil as patrimony, and is further enabled through the scientific indeterminacy of oil's impacts on fish. In order to make my claims, I have drawn upon ethnographic research among different fishers and their political leaders, and oil industry and government actors, as well as government documents, to show fishers' less visible ecological practices in the context of the sacrifice zone.

The fishers' livelihood practices are essentially based on mobility. In the everyday of fishing, Tabasco's diverse riverine and sea fishers constitute themselves as free and mobile hunters through their closeness with environment, fishing equipment and fish species. Their narratives and embodied practices reflect this entanglement with the sea environment.

The everyday claims of fishers about seismology, oil and the disappearance of fish reflect their perspective on their own marginalisation within marine environmental governance. While fishers 'know' the oil industry is the principal cause of their decreased catches, they have diverging understandings about the relations between seismology, hydrocarbons and marine ecosystems. In fisher leaders' efforts to defend access to their fishing grounds in the Gulf, this knowledge is reshaped into claims that acknowledge oil as patrimony while demanding the right to fishers' coexistence with the industry. However, the fishers' own conceptions of identity, intertwined with their relations with the fish, remain beyond political narratives. Meanwhile, among practising fishers, many access the prohibited offshore zones in any case, thereby defying sanctions.

My analysis of fishers and the oil industry in light of de la Cadena's (2015) and Lerner's (2010) ideas shows how attention to lifeworlds goes beyond political narratives and provides a lens that brings into focus less visible politics concerning the environment. It also suggests that interpreting extractive governance as the production of sacrifice zones highlights how this logic is not unique to Tabasco, but underlies the extraction-based economy globally.

In this article, I have sought to discuss divergence and excess by also showing that perceptions which are not recognised in politics prompt the fisher leaders' labour of translation. In other words, the leaders are rendered subordinate to politics that reflect the logic of sacrificing fish and fishing to patrimony and development and make inevitable the emergence of fisher political leaders who acknowledge oil as patrimony and defend the value of fishing in economic terms. 
Open Access This article is distributed under the terms of the Creative Commons Attribution 4.0 International License (http:// creativecommons.org/licenses/by/4.0/), which permits unrestricted use, distribution, and reproduction in any medium, provided you give appropriate credit to the original author(s) and the source, provide a link to the Creative Commons license, and indicate if changes were made.

Publisher's Note Springer Nature remains neutral with regard to jurisdictional claims in published maps and institutional affiliations.

\section{References}

Acheson, J.M. 1981. Anthropology of fishing. Annu Rev Anthropol 10: 275-316.

Appel, H. 2012. Offshore work: Oil, modularity, and the how of capitalism in Equatorial Guinea. Am Ethnol 39 (4): 692-709.

Arias Rodríguez, J.M., and H. Ireta Guzmán. 2009. Pesca y petroleo en el Golfo de México. Villahermosa: Asociación Ecológica Santo Tomás.

Arroyo, M., and A. Zalik. 2016. Displacement and denationalisation: The Mexican Gulf 75 years after the expropriation. Area 48 (2): 134 141.

Asociación Ecológica Santo Tomás. 2013. Comunidades tabasqueñas demandan a autoridades por contaminación mediante amparo colectivo. http://aestomas.org/comunidades-tabasquenasdemandan-a-autoridades-por-contaminacion-mediante-amparocolectivo/ . Accessed 12 September 2013.

Auyero, J., and D. Swistun. 2009. Flammable: Environmental suffering in an Argentinian shantytown. Oxford: Oxford University Press.

Barry, A. 2013. Material politics: Disputes along the pipeline. Chichester: Wiley Blackwell.

Boucquey, N., L. Fairbanks, K.St. Martin, L.M. Campbell, and B. McCay. 2016. The ontological politics of marine spatial planning: Assembling the ocean and shaping the capacities of "Community" and "Environment". Geoforum 75: 1-11.

Comisión Nacional de Pesca (CONAPESCA), Secretaria de Agricultura, Ganaderia, Pesca y Acuicultura (SAGARPA). 2016. Programa de reactivación económica y desarrollo productivo para Campeche y Tabasco: EPN. Boletín pesquero y acuícola. https://issuu.com/ conapescacomunica/docs/issue. Accessed 5 February 2017.

Comisión Nacional de Pesca (CONĀPESCA). 2013. Anuario estadístico de acuacultura y pesca. Mazatlán: CONAPESCA.

Consejo Ciudadano por el agua del estado de Tabasco. 2014. El cambio climático en Tabasco. De verdad nos importa? Villahermosa: FASOL A.C.

de la Cadena, M. 2010. Indigenous cosmopolitics in the Andes: Conceptual reflections beyond "politics". Cult Anthropol 25 (2): 334-370.

de la Cadena, M. 2015. Earth beings: Ecologies of practice across the Andean worlds. Durham: Duke University Press.

DDiario Oficial (DO). 2003. Acuerdo Secretarial No. 117. Poder Ejecutivo. Secretaria de Marina. DO 11 September 2003.

Diario Oficial de la Federación (DOF). 2014a. Ley de Hidrocarburos, DOF 11-08-2014 Cámara de Diputados del H Congreso de la Unión DOF 11 August 2014

Diario Oficial de la Federación (DOF). 2014b. Ley de Ingresos sobre Hidrocarburos, DOF 11-08-2014. Cámara de Diputados del H. Congreso de la Unión. DOF 11 August 2014. Económica y social desde la innovación tecnológica: de la pesca convencional a la acuicultura rústica ribereña. El caso de la Sociedad Cooperativa Acuario Centleco, SCL en la Colonia Revolución, Municipio de Centla, Tabasco." MSc thesis. México: Universidad Autónoma Metropolitana.
Editorial Staff and Delgado, W. 2016. Áreas petroleras, reabiertas tras 30 años: Beneficios de apertura a la pesca crea controversia. El Expreso de Campeche, 10 May. http://expresocampeche.com/notas/estado/ 2016/05/10/beneficios-apertura-a-la-pesca-crea-controversia/. Accessed 7 March 2017.

Ferry, E.E. 2005. Not ours alone: Patrimony, value, and collectivity in contemporary Mexico. New York: Columbia University Press.

García, K. 2017. Producción de crudo toca nuevo mínimo. El Economista, 26 February. http://eleconomista.com.mx/industrias/ 2017/02/26/produccion-crudo-toca-nuevo-minimo. Accessed 2 May 2017.

Gobierno de México. 2016. Publica ASEA regulación obligatoria para ganadores de licitación de aguas profundas y Trión. http://www.gob. $\mathrm{mx} /$ asea/prensa/publica-asea-regulacion-obligatoria-paraganadores-de-licitacion-de-aguas-profundas-y-trion?state= published. Accessed 8 March 2017.

Greenberg, J.B. 2006. The political ecology of fisheries in the Upper Gulf of California. In Reimagining political ecology, ed. Biersack, A., \& Greenberg, J.B. 121-148. Durham: Duke University Press.

Helmreich, S. 2011. Nature/culture/seawater. American Anthropologist 113 (1): 132-144.

Ingold, T. 2000. The perception of the environment: Essay of livelihood, dwelling and skill. London: Routledge.

Ingold, T. 2011. Being alive: Essays on movement, knowledge and description. London: Routledge.

Inter Press Service, News Agency 2013. Mexican Communities sue Pemex for Environmental Justice. http://www.ipsnews.net/2013/ 05/mexican- communities-sue-pemex-for-environmental-justice/ Accessed 12 December 2016.

Instituto Nacional de Estadística y Geografía (INEGI). 2014. Censos Económicos 2014. http://www.inegi.org.mx/est/contenidos/ proyectos/ce/ce2014/. Accessed 2 May 2017.

Klein, N. 2014. This changes everything. UK: Penguin Random House.

Lerner, S. 2010. Sacrifice zones: The front lines of toxic chemical exposure in the United States. Cambridge: The MIT Press.

Lyons, C., C. Carothers, and K. Reedy. 2016. A tale of two communities: Using relational place-making to examine fisheries policy in the Pribilof Island communities of St. George and St. Paul, Alaska. Maritime Studies 15 (7): 1-23.

Maribus. 2014. World Ocean Review 3: Marine resources - opportunities and risks. http://worldoceanreview.com/en/wor-3-overview/wor-3in-short/. Accessed 17 May 2017.

Martínez, J. 2017. Zona económica, en veda por la federación; la imaginación de EPN. Rumbo Nuevo, 30 March. http://www. rumbonuevo.com.mx/corte-de-caja-471/. Accessed 18 April 2017.

Mendoza Carranza, M., M.L. Martínez Gutiérrez, E.C. Segura Berttolini, A. Romero Rodríguez, and A. Hernández López. 2008. Memorias del taller diagnóstico de la pesca en la Reserva de la Biosfera Pantanos de Centla: la perspectiva social de pesca en los Pantanos de Centla. Ciudad de México: Ecosur Conacyt.

Mitchell, T. 2011. Carbon democracy: Political power in the age of oil. London: Verso.

Morrone, M., and G.L. Buckley. 2011. Mountains of injustice: Social and environmental justice in Appalachia. Athens: Ohio University Press.

Muñoz-Sánchez, P., and J.L. Cruz-Burguete. 2013. Identidades y tendencias migratorias desde la pesca en Chiapas y Tabasco. Convergencia: Revista de Ciencias Sociales 63: 231-257.

Olivares, E., and C. Gómez. 2017. Nuevas manifestaciones en la CDMX contra el 'gasolinazo'. La Jornada, 22 January. http://www.jornada. unam.mx/ultimas/2017/01/22/nueva-marcha-en-la-cdmx-contra-elgasolinazo. Accessed 2 May 2017.

Pálsson, G. 1994. Enskilment at sea. Man 29 (4): 901-927.

Pauwelussen, A. 2016. Community as network: Exploring a relational approach to social resilience in coastal Indonesia. Maritime Studies $15(2): 1-19$ 
Paxton, A.B., J.C. Taylor, D.P. Nowacek, J. Dale, E. Cole, C.M. Voss, and C.H. Peterson. 2017. Seismic survey disrupted fish use of a temperate reef. Marine Policy 78: 68-73.

Payne, J.F., C.D. Andrews, L.L. Fancey, J. Guiney, A. Cook, and J.R. Christian. 2012. Are seismic surveys an important risk for fish and shellfish? Bioacoustics 17: 1-3.

Quist, L.-M., and A. Nygren. 2015. Contested claims over space and identity among fishers and the oil industry in Mexico. Geoforum 63: 44-54.

Quist, L.-M., and P. Rinne. 2017. The politics of justification: Newspaper representations of environmental conflict between fishers and the oil industry in Mexico. Environmental Values 26 (4): 457-479.

Rendón von Osten, J., and G.J. Villalobos Zapata. 2010. Amenazas a la biodiversidad: Problematica. In La biodiversidad en Campeche: Estudio de Estado, ed. G.J. Villalobos Zapata. and J. Mendoza Vega, 546-564. Tlalpan: Comisión Nacional para el Conocimiento y Uso de la Biodiversidad (Conabio). Campeche: Gobierno del Estado de Campeche, Universidad Autónoma de Campeche, El Colegio de la Frontera Sur.

Saury Arias, J.R. 2010. La comunidad pesquera y sus procesos de organización.

Sawyer, S. 2016. Crude contamination: Law, science, and indeterminacy in Ecuador and beyond. In Subterranean estates: Life worlds of oil and gas, ed. H. Appel, A. Mason, and M. Watts, 126-146. Ithaca: Cornell University Press.

Sellers, Christopher C. 2016. La debilidad de la legislación ambiental en México ante la apertura energética. New York Times, 9 December. https://www.nytimes.com/es/2016/12/09/mexico-en-camino-aconvertirse-en-un-estado-ambiental-fallido/. Accessed 3 March 2017.
Soto, L.A., A.V. Botello, S. Licea-Durán, M.L. Lizárraga-Partida, and A. Yáñez-Aranciaba. 2014. The environmental legacy of the Ixtoc-I oil spill in Campeche Sound, southwestern Gulf of Mexico. Frontiers in Marine Science 1 (57): 1-9.

Spitzer, M. 2015. Return of the gar. Denton: University of North Texas Press.

State of Tabasco. 2017. Juzgado cuarto del distrito. Juicio de amparo 1726/2013-III. 10 March.

Stengers, I. 2005. Introductory notes on an ecology of practices. Cultural Studies Review 11 (1): 183-196.

Televisa. 2017. En febrero iniciará explotación de yacimientos en Tabasco y Veracruz. http://noticieros.televisa.com/ultimas-noticias/ estados/2017-01-23/en-febrero-iniciara-explotacion-deyacimientos-en-tabasco-y-veracruz/. Accessed 2 May 2017.

United States Energy Information Administration (US EIA). 2016. How much petroleum does the United States import and export? https:// www.eia.gov/tools/faqs/faq.php?id=727\&t=6. Accessed 2 May 2017.

Valenzuela Pérez, L.F. 2016. "Coppered lives: The Chilean sacrifice zone of Quintero Bay." PhD thesis. Sydney: University of Sydney.

Vidal Hernández, L.E., I. Paramo Romero, L.A. Soto, and E. Rivera Arriaga. 2012. Legal framework for the offshore operations of the Mexican oil industry from a systemic environmental perspective. Ocean and Coastal Management 58: 9-16.

Zalik, A. 2006. Re-regulating the Mexican Gulf. CLAS Working Papers, Center for Latin American Studies. Berkeley: University of California Berkeley. 